\title{
CRITICISING STATELESSNESS STATUS AND ASEAN'S ROLE TOWARDS ROHINGYA ATROCITIES
}

\author{
Naeli Fitria \\ Prodi Hubungan Internasional, Universitas Pertamina \\ Email: naelifitria@gmail.com
}

\begin{abstract}
Rohingya statelessness is increasingly recognized as a serious, worldwide human rights violations concern. The rejection of Rohingya ethnic group by Myanmar Government has resulted in life-threatening circumstances. International protocol, such as, the 1954 Convention relating to the Status of Stateless Persons, as a tool in giving shelter for stateless people are still weak in the implementation. Major drawback in providing shelter for Rohingya refugees which have been implemented by Bangladesh Government, however, has inseparable factor in upholding human rights for refugees. To date, ASEAN has poor human rights mechanism in addressing human rights violations issue within the region. The avoidance taken by ASEAN reflected the concept of negligence. Thus, this paper sought to examine the factors of Citizenship and ASEAN's Negligence in addressing Rohingya issue.
\end{abstract}

Keywords: Statelessness; Status; ASEAN; ROHINGYA

\section{INTRODUCTION}

Historically, Rohingya is a group of Muslim minorities who has lived in Rakhine State which located between Myanmar and Bangladesh border (Kovács-zsankó, 2017). Their predecessors were lived coexist in the area namely Rakhine State with Bhuddist tribe until the term "Rohingya" was misused for political means (Kovács-zsankó, 2017). Therefore, the crisis of Rohingya status was begun from this point

Political dynamic in Myanmar that occurred between Buddhist tribe and Rohingya in Rakhine State has created severe situation in this area. (Global Center for the Responsibility to Protect, 2014) argue that Buddhist sectarianism has more powerful impact in intervening Rakhine State in order to occupy this area. In addition, Bhuddist is the majority of Myanmar population notably in Rakhine State namely Bamar which possess military forces called Tatmadaw (Global Center for the Responsibility to Protect, 2014). Approximately 200 people died and 120.000 people were become homeless when the outrage in June and October 2012 occurred against Muslim in Rohingya by Bhuddist tribe (Global Center for the Responsibility to Protect, 2014). Such human rights violations have 
resulted in international response towards Myanmar Government to take actions to protect its people.

In the relations to the above, it has become increasingly difficult to separate Myanmar with its military junta system within the country. (ASEAN Parliamentarians for Human Rights, 2018) observed that the Arakan Rohingya Salvation Army (ARSA) did major human rights infringement on 25 August 2017 towards Muslim Rohingya, such as, sexual abuse, mass murder even such atrocity is categorized as ethnic cleansing by the UN High Commission on Human Rights.

The situation has become more severe due to unwillingness of Myanmar Government to recognize Rohingya as a part of their citizens. (Global Center for the Responsibility to Protect, 2014) found that since citizenship survey in 1983, Myanmar Government neglected to admit Rohingya citizenship status, yet, stated that Rohingya ethic group as Bengali outsider whom have no rights to live in Myanmar boundaries. This case has led to more complex situation for Rohingya ethnic group.

Furthermore, the role of Association of Southeast Asia Nations (ASEAN) as a regional organisation in which Myanmar is one of the member states is questioned due to this unresolved problem. (Kundu, 2015) points out that non-interference principle which has become characteristic of ASEAN has left Rohingya case lack of attention and put Rohingya in isolated situation.

Thus, this paper attempts to criticize both the concept of Statelessness and ASEAN's role in resolving major human rights violations towards Rohingya ethnic group. The first part will discuss the status of Rohingya and Statelessness. The second part will examine ASEAN's delicacy towards this issue. At the end, this essay will argue that the absence of international awareness and non-interference principle of ASEAN remain abandon this atrocity unresolved.

\section{LITERATURE REVIEW}

\section{Problem of Citizenship: Rohingya and Statelessness}

As a legal basis, Myanmar government has the 1982 Citizenship Law to ensure the rights of their citizens. However, the implementation of such regulation does not appropriate to date. (International Commission of Jurists, 2019) reported that Myanmar government applies discriminatory practice and diminishes international human rights law. In addition, 
international human rights law deliberately emphasise the protection to all people and not does not restrict it to merely people who hold legal status (International Commission of Jurists, 2019).

The aforementioned background, however, does not encourage Myanmar government to safeguard the ethnics notably Rohingya. It is arguably that the status of Rohingya ethnic group as stateless persons remains in critical situation until recently. (UNHCR, 2014) defines stateless persons in the 1954 Convention relating to the Status of Stateless Persons as "a person who is not considered as a national by any State under the operation of its law." In other words, State has power through law system over its people or people who are living in their territory.

In relations to the above, the 1982 Citizenship Law in Myanmar has discriminatory character. This affecting the people in Myanmar with approximately $25 \%$ eventually lack of legal status then become stateless, comprising the whole ethnic groups. Notwithstanding Section 347 of the 2008 Constitution implies, "The Union shall guarantee any person to enjoy equal rights before the law," other legal provisions nonetheless contradicts with such pledge and with the fundamental value of international human rights law, by limiting rights only for the citizens who hold legal identity. Another consequences faced by stateless persons in Myanmar are the limited access to several kind of discrimination, mainly before the State. It is proven by the fact that they have no access to marriage registration and education (International Commission of Jurists, 2019).

The urgency of international response and action towards this human rights breach has put Rohingya ethnic group in political agenda. It seems that such convention is highly tight to law and political system within a state. It is proven by the fact that the number of stateless persons in the world remain increase even though the practice of the aforementioned international conventions have been applied (Edwards and Waas, 2014).

Since Burma (former name of Myanmar) gained their freedom of colonialism in 1948, protest against Rohingya mounted then triggered Myanmar both government and citizens neglect Rohingya presence (Milton et al., 2017). In addition, the oppression by radical Buddhist and Burma Independence Army towards Rohingya soared during 1940 and 1947 which murdered 100.000 Rohingya people and deported 50.000 of them into the border of Bangladesh namely East Bengal (Milton et al., 2017). Following that, however, the abusive practice of law enforcement in Myanmar towards Rohingya ethnic group is undeniable in creating flow of Rohingya people to move to more secure area. 
The mass migration of Rohingya people to the closest area has marked as the beginning of refugee crisis. Bangladesh in 1978 started to face the coming of approximately 250.000 Rohingya refugees (Milton et al., 2017). Since then, (Milton et al., 2017) also argue that Bangladesh Government denied the presence of Rohingya refugees then asked Myanmar Government to take responsibility of its people. Therefore, complex situation has raised and it seems undermining the relations between Myanmar and Bangladesh.

Notwithstanding, it is also arguably that the ability of stateless persons in affecting state security has created critical circumstances for Bangladesh. The flow of people who fled to Bangladesh has challenged the relations between those two countries. (Institute on Statelessness and Inclusion, 2017) reported that the urgency of major human rights violations against Rohingya ethnic group has triggered the United Nations (UN) Secretary General to warn international communities to take action to safe Rohingya people. Following that, due to significant numbers of Rohingya refugees coming to Bangladesh, Bangladesh Government also urged Myanmar Government to implement repatriation policy in receiving back Rohingya people in humane treatment and allow to open access for the UN to take responsibility in accelerating peaceful reconciliation (Institute on Statelessness and Inclusion, 2017). Therefore, such initiative has created more desirable situation for Rohingya people to live in more peaceful condition in spite of Myanmar behaviour which still reject them.

However, the openness actions of Bangladesh Government to accept and accommodate Rohingya people has resulted in more critical situation in the border. (Rahman, 2010) reported that at the beginning, Bangladesh Government was ready to create shelter for Rohingya refugees and ask for providing assistance together with the UN. Meanwhile, in the process of accommodating, unexpectedly Bangladesh Government declared to stop the process (Rahman, 2010). Such inconsistency is more likely related to irregular movement of people which in due course become uncontrolled and at the same time the decision made by Bangladesh Government was premature. This is proven by several threats which were occurring during the process of acceptance. (Rahman, 2010) also reported that the presence of significant number of Rohingya refugees in Bangladesh has created perplexing situation mainly for Bangladesh's state security. In order to survive and support their life, some of refugees unfortunately have relations to the practice of drug trade and terrorism practice (Rahman, 2010).

In addition to the above, lack of control and observation by Bangladesh Government has triggered crimes to occur notably in border in which Rohingya refugees are living. 
(Rahman, 2010) observed that in refugee camps particularly in Cox's Bazar District are prone to be strategic place for mobilizing extremist movements. Such operation were occurred between Rohingya Solidarity Organization (RSO) and the Arakan Rohingya Islamic Front (ARIF) due to rebellion actions of Rohingya refugees in struggling for their rights to live as refugees and self-determination towards Bangladesh Government (Rahman, 2010). However, as the consequences, the insurgency has shaped vicious cycle for other vulnerable refugees, for instance, women and children whom become victims because of the conflict.

Furthermore, (ASEAN Parliamentarians for Human Rights, 2018) investigated that Bangladesh Government does not acknowledge refugee status of Rohingya people to date which led to poor access for basic needs, such as, food, health, education even security for Rohingya refugees. (Milton et al., 2017) also found the relations to such condition pertaining to lack of policy made by Bangladesh Government in giving protection for Rohingya people. Such ambiguity of situation seems that both Myanmar and Bangladesh Governments do not put human rights as their priorities. This is evidenced by suffering condition, for instance, sexual violence and racial discrimination which are faced by Rohingya ethnic group (Milton et al., 2017).

Uncertain acknowledgement both by Myanmar and Bangladesh Government has also led to omission of Rohingya people's rights. (Sigona, 2016) states that the status of 'stateless' persons which has less international attention has put them in the edge condition due to insufficient citizenship proven data. Such unfortunate situation has driven stateless persons to blocked access of human rights in order to survive in the most vulnerable area where they end up (Sigona, 2016). Such circumstances of stateless persons, however, particularly Rohingya ethnic group is absolutely living in impoverished condition which possible to led them to suffer from famine even death. It is evidenced by the fact that high number of death of Rohingya children mounted to 224 children died per 1000 new born which more serious due to four times higher than other Myanmar population (Saeidi et al., 2017). In addition, (Institute on Statelessness and Inclusion, 2017) also found that vast majority of Rohingya ethnic group has suffered from critical psychological damage, famine and injury because of bullet fire.

Interestingly, despite vulnerable conditions of stateless persons like Rohingya ethnic group which has driven international pressure towards Myanmar Government, it also reflected that the presence of stateless persons has robust influence to Myanmar Government. (Grygiel, 2009) argue that the existing of stateless persons has potential to 
confront with their government and trigger safety dispute of the state. In addition, the advancement of technology and press in reporting news worldwide has also threaten the stability of political cohesion of the state (Grygiel, 2009). It is proven by intense of mass media publicity in addressing Rohingya atrocities which caused the United State President, Barrack Obama, continuing sanctions toward Myanmar in 2 May 2013 if the Government has no willingness to stop this major human rights abuses (Global Center for the Responsibility to Protect, 2014). However, such sanction seems vague in the implementation since one of prominent leader in Myanmar, Aung San Suu Kyi has normalized both countries relations and denied the atrocities.

Inconsistency and ambiguity of Myanmar Government behaviour is considerably affected by the decision makers within the state notably the most influential leader who was awarded Nobel Peace Prize, Aung San Suu Kyi. It is unfortunate that such awarded does not reflect the real condition which is still occurring in Rakhine State. (House of Commons of the United Kingdom, 2018) has proven that by reporting that the role of Aung San Suu Kyi has diminishing critical situation of Rohingya people. Aung San Suu Kyi opted to be in the contrary position in solving this genocide problem and remain absence in echoing this serious case both inside and outside the state (House of Commons of the United Kingdom, 2018). Such dissatisfaction shown by international community has provoked world leaders to make contribution in providing assistance for Rohingya people.

Furthermore, pertaining to the pressure in tackling Rohingya crisis, Myanmar Government has consequence to be interrupted by international action. Agreed in 2005 United Nations World Summit, the Responsibility to Protect pushed every state must oblige to secure its people from any kind of human rights abuses including murder, sexual assault even ethnic cleansing (Global Center for the Responsibility to Protect, 2014). However, this instrument remains silent in influencing Myanmar Government even they become more immune from intervention. It is evidenced by the fact that Myanmar President, Thein Sein, responded to the forewarning by the UN High Commissioner for Refugees (UNHCR) in June 2012 that Myanmar Government has right to maintain their citizens well but not with illegal persons hereby Rohingya ethnic group (Global Center for the Responsibility to Protect, 2014).

The denial of Myanmar Government to receive back Rohingya people pertaining to repatriation policy is arguably due to no legal documents which prove their citizenship status. (Institute on Statelessness and Inclusion, 2017) stated that the non-refoulement scheme which is adopted by Myanmar Government will accept legal persons coming to 
Myanmar including Rohingya ethnic group. Yet, they reiterated that persons without residents identification cards, however, will be deported (Institute on Statelessness and Inclusion, 2017). Such practice seems showing Myanmar Government's resistant position in facing Rohingya people even politicized it . It is proven when the implementation in validating residence was forcing in which Myanmar Government in 2014, Rohingya people who registered faced documents are retained (Institute on Statelessness and Inclusion, 2017). Such documents seizure also related to the law enforcement related to the Burmese Citizenship Act of 1982 (Rahman, 2010).

Perplexing condition of stateless persons also related to both condition and legal status. (Edwards and Waas, 2014) suggested that legal aspect hereby de jure realm of citizens is matter when stateless persons need humanitarian assistance to save their life. Meanwhile, it has become unfortunate to protect stateless persons even though in real or de facto condition they are living in desperate situation (Edwards and Waas, 2014). Such heated controversy has reflected the condition of Rohingya people who live in the middle of both political interest of Myanmar Government and limited access by international humanitarian relief agency to provide protection. This is evidenced by Myanmar Government which warned UNHCR to leave Myanmar notably in Rohingya ethnic group area in Rakhine State the Government decided pertaining to their power (Institute on Statelessness and Inclusion, 2017).

Moreover, warning from Myanmar Government for UNHCR to comply with their rule to be gone from Rakhine State has shaped resistance from UNHCR itself. (Asia Pacific Refugee Rights Network, 2017) suggested that UNHCR still has role in controlling Rakhine State and making efforts in protecting Rohingya people from abusive operation by Myanmar army as well as inadequate law enforcement by Myanmar Government. In addition, in the process of supervising the area should be conducted through steady steps towards Myanmar Government, for example, influencing them to accept negotiation in upholding the rights to citizenship for Rohingya people (Asia Pacific Refugee Rights Network, 2017). Therefore, providing shelter and humanitarian relief for Rohingya people is not a straightforward process mainly when dealing with Myanmar Government. It is more likely to create more conflict of interest between international agency and state authority which possible to turn to ineffective protection even creating more complex cycle for those vulnerable Rohingya refugees.

In relations to the above, such UNHCR attempt also in line with the implementation of international agreement hereby the 1974 Convention on the Reduction of Statelessness. 
Interestingly, the application of such convention has broaden its scope not merely in member states of 1954 and 1961 convention but also beyond (Blitz, 2011). The spirit in protecting stateless persons also for promoting human rights around the world, so that, everyone in the face of human rights can achieve their rights regardless their background.

Challenges in addressing stateless persons notably in implementing repatriation policy between Bangladesh and Myanmar also revealed tenuous enforcement of international instruments. (Edwards and Waas, 2014) argue that unclear set of rules in the 1954 Convention mainly about statelessness status determination (SSD) does not accelerate the process in protecting stateless persons to date. Adversely, not all parties have commitment in setting SSD scheme as their priority in upholding human rights values (Edwards and Waas, 2014). This is evidenced by dissatisfied result of research which conducted in 2011 by the UNHCR in terms of providing shelter for stateless persons related refugees (SSD) (Edwards and Waas, 2014). This research also reiterated that inconsistency of DSS implementation has resulted in more serious consequences faced by stateless persons to live in desperate condition and no access to escape (Edwards and Waas, 2014). Such legal instrument is more likely reflects complicated situation mainly for Bangladesh Government in making decision to receive significant numbers of Rohingya people due to denial of Myanmar Government. In addition, the absence attention of international community pertaining to DSS seems that states have become more silent in coping up with stateless persons problem.

Furthermore, beside unclear standing point of stateless persons in international agreements, other matter which has shown restrained policy implementation is tightly related to prolonged time in which the policies or rules are ratified and adapted to the national law of each state. (Berkeley, 2009) claimed that in the 1954 Convention Relating to the Status of Stateless Persons, only 62 states which agreed to implement, yet, in the 1961 Convention on the Reduction of Statelessness, only 33 states authorized it. In addition, (Trounson, 2017) observed that the reason why ratification takes long time before entering into force even implementation, states which attempt to ratify international convention has to struggle with their own tribunal system.

Notwithstanding, since the attempt of international agency and international instruments in providing shelter and supporting humanitarian assistance for stateless persons is stuck, a question appears in addressing Association of Southeast Asian Nations (ASEAN)'s role in solving Myanmar atrocities in which Myanmar is one of the ASEAN Member States (AMS). 


\section{Problem of Harm: ASEAN's Negligence towards Rohingya Crisis}

Assessing Rohingya problem cannot be separated from one of the most important factors namely problem of harm. According to (Hadiwinata, 2017) in which such factor rooted in Andrew Linklater's Cosmopolitan concept, government is possible to harm their own citizens deliberately in order to survive and to secure state's power. It is proven by the fact that people in Myanmar is consisted of 40 percent minorities and ethnic groups and they are separated by various interest in defeating against the Government. The unstable situation often occurs between Kachin, Karen, Northern Shan and Rakhine as the ethnic groups and the Burmese Army as the ultra-nationalistic Buddhist monks (Dussich, 2018). The clash arose when the Burmese Army responded the actions murderously which resulted in gross number of human rights violations, for instance, torture, atrocities, sexual abuses and masskilling. The situation has been worse due to the military operation of Burmese Army who have freedom of liability in attacking Rohingya minorities which categorized as severe human rights breach by the Government (Dussich, 2018).

In relations to the above, in resolving Rohingya problem between Bangladesh and Myanmar also reflects the Responsibility to Protect (R2P) concept. (Hadiwinata, 2017) stated that the deliberated harm caused by government to their own citizens dragged international attention to employ humanitarian intervention to resolve the situation. One of the international efforts is the presence of UNHCR. (Köhler, 2018) highlights that R2P is not a legal obligation of a state to comply with international law but tend to be a moral obligation. States have responsibility to protect their citizens from any form of harm both from internal and external. When the states unable to do so, the United Nations (UN) has a right to intervene in order to ease the conflict (Köhler, 2018).

The source of the R2P implementation in Myanmar was from the report of Special Rapporteur who disclosed the human rights violations towards Rohingya ethnic minority group in Rakhine state. The report encouraged international community to pay attention to the human rights violations in Myanmar in supporting the UN to implement stringent actions (Köhler, 2018).

It is becoming increasingly difficult to ignore that Rohingya crisis has emerged as regional security threat especially for Southeast Asian countries. Perplexing efforts made by international agency such as UNHCR has called ASEAN to take action in helping its member state hereby Myanmar. Between ASEAN Member States (AMS), merely the Philippines and 
Cambodia which signed the 1951 Convention Relating to the Status of Refugees (Shivakoti, 2017). In addition, (Southwick, 2015) claimed that it has become urgent for ASEAN to tackling this major human rights violation due to its obligation as international community towards 1948 Convention on the Prevention and Punishment of the Crime of Genocide. From those two both regional and international instrument, it seems that more complex situation is faced by ASEAN at the same time. ASEAN is more likely to manage its internal affairs first rather than comply with external pressure (particularism).

The lack of legal framework in dealing with stateless persons and refugees in ASEAN has led to absence actions of ASEAN when human rights abuses occur in its member states area. Despite of little attention of the world towards Rohingya in some conventions, unfortunately, ASEAN also only prioritize 2007 ASEAN Declaration on the Protection and Promotion of the Rights of Migrant Workers and not including the rights of stateless persons and refugees (Shivakoti, 2017). Such gap has led to unaware behaviour of ASEAN and its member states pertaining to the situation which is occurring in Rohingya.

Interestingly, such unaware response by member states towards Rohingya issue reflected vague rule that stated in the ASEAN Human Rights Declaration (AHRD). (Southwick, 2013) argue that the issue that raise pertaining to AHRD is mainly related to the implementation of human rights value in ASEAN. ASEAN should respect national or domestic rules of each AMS in order to stabilize regional and domestic security condition (Southwick, 2013). However, it has shown more obvious obscurity of the AHRD and has given leeway for human rights abuses to occur on behalf of state power. Consequently, such gap apparently possible for Myanmar Government to defend its position to remain silent in Rohingya ethnic cleansing and still acknowledging them as non-Myanmar citizens. Therefore, it is difficult to blame and interfere Myanmar since the use of non-interference principal has benefited them in maintaining state power.

ASEAN Intergovernmental Commission on Human Rights (AICHR) has emerged as an overarching body in maintaining human rights cases in ASEAN (Ramos Gamez, 2017). It has mandate to preserve and elevate human rights in ASEAN (AICHR, 2012). However, it has become unfortunate since this body has no mandate in receiving reports or complaints regarding human rights abuses. From this point, it can be seen that ASEAN's delicacy seems giving more sign that ASEAN has no proper human rights mechanism in dealing with statelessness and refugees. It is proven by the fact that ASEAN has no central court like European Union to cope up with human rights violations in the region (Ha and Htut, 2016). 
Another consequence of the absence legal institution in dealing with human rights abuses in ASEAN is the exodus of Rohingya refugee crisis which resulted in massive human trafficking crime. This unlawful act has expanded to other states in Southeast Asian region, for instance, Malaysia and Indonesia. The escape of Myanmar refugees to Malaysia and Indonesia has revealed more serious human trafficking cycle on their journey especially through sea (Shivakoti, 2017). Again, ASEAN is solely concentrate on the struggle of ASEAN Convention Against Trafficking in Persons, Especially Women and Children (ACTIP) which unfortunately excluding refugees and stateless persons status on this convention (Ha and Htut, 2016).

Furthermore, intricate situation continues about the ineffective role of international agency in Rakhine State in order to providing humanitarian assistance. In the midst of cruel massacre against Rohingya people, there is a notion which stated that the presence of international agency, for instance, UNHCR coming inside the conflict area is responded by Rohingya people as suspicious measure (Ha and Htut, 2016). (Ha and Htut, 2016) also suggested that instead international community, it is possible to be accepted if ASEAN establish humanitarian emergency relief. Therefore, such negative reaction eventually still leave this atrocities unresolved.

It has become critical when Rohingya problem appears in several ASEAN meetings including ASEAN leaders meeting. (Human Rights Watch, 2019) reported that during ASEAN Summit in 2018, ASEAN discussed the Rohingya atrocities but limited to the repatriation mechanism, however, such issue was merely treated as "a matter of concern" and overlooked the Government harm towards human rights violations. In this summit also ASEAN'S Emergency Response and Action Team (ERAT) released a "preliminary needs assessment" on repatriation for estimated one million Rohingya refugees in Bangladesh. The assessment report which contains 56 pages, in which the research conducted by Human Rights Watch, shows that it does not incorporate Rohingya refugee opinion and the thorough report diminishing the Myanmar government human rights abuses which resulted in mass displacement. Even the term "Rohingya" is not availed as a reflection of rejecting ethnic identity (Human Rights Watch, 2019).

\section{The Problem of Community Within ASEAN as a Regional Institution}

Furthermore, ASEAN principle's namely non-interference has become major obstacle in unraveling Rohingya crisis. (Ha and Htut, 2016) claimed that this principle is absolutely put ASEAN in safe position by not condemning Myanmar publicly. Instead, ASEAN taking 
step to remain tranquil and let Myanmar find the solutions towards its people through its domestic or national law (Ha and Htut, 2016). ASEAN in practice, however, implemented this non-interference principle. This is evidenced by sensitivity in using label "Rohingya" in which ASEAN has refrained not to echoing this in any ASEAN forum since it is possible to turn to regional disunity (Ha and Htut, 2016).

In relations to the above, Hadiwinata (2017) denotes that negligence occurs when states or international organisations fail in avoiding their citizens or member states notably the minority from their basic rights. Such concept rooted from Andrew Linklater's critical approach towards international politics which explaining five categories of problem of harm. One of those concepts highlight negligence aspect that states often fail to fulfil its duty for upholding human rights. This is proven by irresponsible actions of ASEAN which revealed in the $14^{\text {th }}$ ASEAN Summit in 2009 when Chairman's Statement avoided in mentioning words "illegal migrants in the Indian Ocean" rather than "Rohingya" and the negotiation process was unsuccessful in reaching agreement (Ha and Htut, 2016). Therefore, such indecision behaviour of ASEAN is absolutely humiliated in the midst of gross human rights violations even it is categorized as ethnic cleansing. ASEAN resistance in being faithful with "ASEAN Way" towards non-interference principle has developed an alternative step in dealing with human rights issues in ASEAN.

\section{CONCLUSION}

Rohingya has tremendous and prolonged records of human rights abuses. Efforts by international communities are made, for instance, the 1954 Convention relating to the Status of Stateless Persons and 1961 Convention on the Reduction of Statelessness yet, unfortunately in the implementation always facing challenge. One of the challenge is not all parties or signees oblige to the commitment in protecting stateless persons and refugees.

Perplexing condition which suffered by Rohingya ethnic group mainly rejected by Myanmar Government to be its citizens has left them to live in desperate and vulnerable situation. In spite of the fact that Bangladesh has provide shelter in its border are namely Cox's Bazar District, the intention of Bangladesh Government has diminished since that are become a fertile land for mobilizing extremist movements which took rebellion against Bangladesh Government due to difficulty to achieve their rights to be refugees.

Furthermore, international agency, for example, UNHCR has limitation in providing assistance through humanitarian relief. In addition, ASEAN as a regional organization in 
which has absolute responsibility for its member state remain weak in dealing with this problem mainly its non-interference norm. Therefore, major improvements should be undergone. International community must oblige and urge all states to create a legallybinding agreement and ASEAN should amend or take into consideration in revisiting its non-interference principle which has become prolonged obstacle in resolving all human rights problems within the region.

\section{REFERENCES}

AICHR (2012) A Brief History of the ASEAN Intergovernmental Commission on Human Rights (AICHR). Available at: http://aichr.org/about/.

ASEAN Parliamentarians for Human Rights (2018) 'The Rohingya crisis', 33(6), pp. 1-2. doi: $10.1111 / 1467-8322.12389$.

Asia Pacific Refugee Rights Network (2017) 'The Rohingya Refugee Crisis and Building Capacity for Rapid and Predictable Humanitarian Response', (July), pp. 1-10.

Berkeley, B. (2009) 'Stateless People, Violent States', World Policy Journal, 26(1), pp. 315. doi: 10.1162/wopj.2009.26.1.3.

Blitz, B. K. (2011) Policy responses and global discourses on the rights of non-citizens and stateless people, Statelessness in the European Union: Displaced, Undocumented, Unwanted. doi: 10.1017/CBO9780511921438.005.

Dussich, J. P. J. (2018) 'The Ongoing Genocidal Crisis of the Rohingya Minority in Myanmar', Journal of Victimology and Victim Justice, 1(1), pp. 4-24. doi: $10.1177 / 2516606918764998$.

Edwards, A. and Waas, L. Van (2014) The Oxford Handbook of Refugee and Forced Migration Studies. Edited by E. Fiddian-Qasmiyeh et al. Oxford: Oxford University Press.

Global Center for the Responsibility to Protect (2014) 'Anti-Muslim Violence in Burma / Myanmar and the Responsibility to Protect', (January).

Grygiel, J. (2009) 'The Power of Statelessness', Policy Review, (154), p. 35. Available at: http://content.ebscohost.com.library3.webster.edu/ContentServer.asp?T=P\&P=A $\mathrm{N} \& \mathrm{~K}=37359751 \& \mathrm{~S}=\mathrm{R} \& \mathrm{D}=\mathrm{f5h} \&$ EbscoContent $=\mathrm{dGJ}$ yMNHr7ESeqLQ4xNvgOL Cmr0qep7NSsqm4SrWWxWXS\&ContentCustomer=dGJyMPGut1G1qLdKuePfg eyx44Dt6fIA\%5Cnhttp://library3.webster.edu/login?url=http://se.

Ha, H. T. and Htut, Y. (2016) 'Rakhine Crisis Challenges ASEAN' s Non-Interference Principle', (70), pp. 1-8.

Hadiwinata, B. S. (2017) Studi dan Teori Hubungan Internasional: Arus Utama, Alternatif 
dan Reflektivitas. Jakarta: Yayasan Pustaka Obor Indonesia.

House of Commons of the United Kingdom (2018) Bangladesh and Burma: the Rohingya crisis. Available at: https://publications.parliament.uk/pa/cm201719/cmselect/cmintdev/504/504.pdf.

Human Rights Watch (2019) ASEAN: Don't Whitewash Atrocities Against Rohingya. Available at: https://reliefweb.int/report/myanmar/asean-don-t-whitewashatrocities-against-rohingya.

Institute on Statelessness and Inclusion (2017) 'Repatriation, Statelessness and Refugee Status: Three Crucial Issues in the Unfolding Rohingya Crisis Statelessness', (October), pp. 7-9. Available at: http://www.institutesi.org/repatriation_statelessness_and_refugee_status_2017.pdf

International Commission of Jurists (2019) 'Citizenship and Human Rights in Myanmar : Why Law Reform is Urgent and Possible A Legal Briefing’, (June).

Köhler, I. (2018) 'Responsibility to protect Rohingya Muslims in Myanmar', (Faculty of Law Lund University).

Kovács-zsankó, G. (2017) ‘Rohingyas , a Non-Existing Nation’, (March), pp. 39-48.

Kundu, S. (2015) 'IDSA Issue Brief', pp. 1-14. doi: 10.7327/cerei.2013.09.03.

Milton, A. H. et al. (2017) 'Trapped in statelessness: Rohingya refugees in Bangladesh', International Journal of Environmental Research and Public Health, 14(8), pp. 18. doi: 10.3390/ijerph14080942.

Rahman, U. (2010) 'The Rohingya refugee: A security dilemma for Bangladesh', Journal of Immigrant and Refugee Studies, 8(2), pp. 233-239. doi: $10.1080 / 15562941003792135$.

Ramos Gamez, K. (2017) 'Examining the ASEAN Intergovernmental Commission on

Human Rights (AICHR): the Case Study of the Rohingya Crisis', (June).

Saeidi, M. et al. (2017) 'Children, the Main Victims of Ethnic Violence in Myanmar', 5(47), pp. 6173-6178. doi: 10.22038/ijp.2017.26317.2252.

Shivakoti, R. (2017) 'ASEAN's role in the Rohingya refugee crisis', Forced Migration Review, (56), pp. 75-77.

Sigona, N. (2016) 'Everyday statelessness in Italy: status, rights, and camps', Ethnic and Racial Studies. Taylor \& Francis, 39(2), pp. 263-279. doi: 10.1080/01419870.2016.1105995.

Southwick, K. (2015) 'Preventing Mass Atrocities Against the Stateless Rohingya in Myanmar: A Call for Solutions’, 68(2), pp. 137-157. 
Southwick, K. G. (2013) 'Bumpy Road to the ASEAN Human Rights Declaration'.

Trounson, A. (2017) Nowhere People Have a Right to Somewhere. Available at: https://pursuit.unimelb.edu.au/articles/nowhere-people-have-a-right-to-somewhere (Accessed: 17 April 2018).

UNHCR (2014) 'Text of the 1954 Convention relating to the Status of Stateless Persons'. 